\title{
TUNNELLING AND OTHER ENGINEERING WORKS IN VOLCANIC ENVIRONMENTS: SOUSAKI AND THESSALY
}

\author{
Tsatsanifos C. ${ }^{1}$, Kontogianni $\mathrm{V}^{2}$, and Stiros S. ${ }^{2}$ \\ ${ }^{1}$ PANGAEA Consulting Engineers Ltd., 131, Kifissias Ave.11524 Athens, pangaea@otenet.gr \\ ${ }^{2}$ GeodesyLab., Dept of Civil Engn, Patras University,vkont@upatras.gr,stiros@upatras.gr
}

\begin{abstract}
This study is inspired by the impacts on a tunnel of the Sousaki volcano, in the vicinity of Corinth and examines possible impacts of the Quaternary volcanism on major engineering works in Thessaly.

The Sousaki volcano, at the NW edge of the Aegean Volcanic Arc has been associated with important volcanic activity in the past, but its current activity is confined to geothermic phenomena. A tunnel for the new Athens-Corinth High Speed Rail was excavated through the solfatara of the volcano, an area characterized by numerous faults and physical cavities. High temperatures and geothermal gases released in the underground opening through the faults caused disturbance to the tunnel construction, need for supplementary investigations and adoption of special measures to maintain tunnel stability.

Experience from the tunnel at Sousaki indicates that similar risks may be faced in future major engineering works in other regions of Greece. Such an example is the area of Microthives and Achillio, Magnesia, Thessaly. Tunnels for the new highway and railway networks constructed or planned through at least two volcanic domes and other main engineering works may also face volcano-associated effects. Optimization of the network routes in combination with special construction techniques and safety measures need to be followed for minimization of such volcanic risks.
\end{abstract}

Key words: faults, Sousaki, Thessaly, tunnels, volcanism.

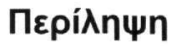

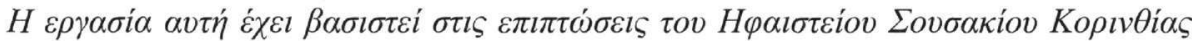

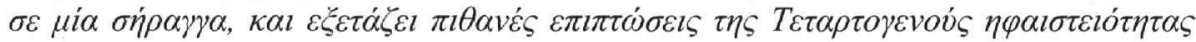

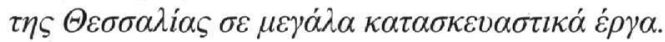

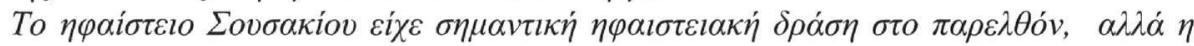

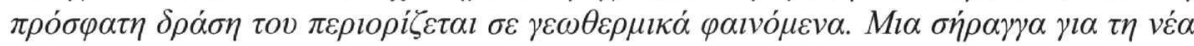

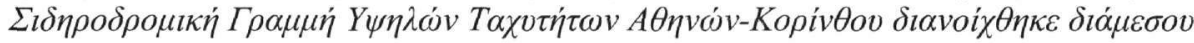

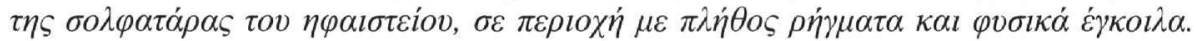

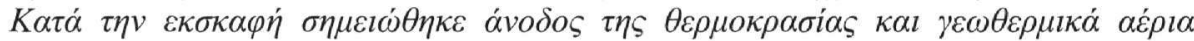

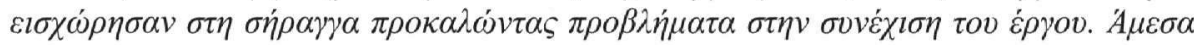

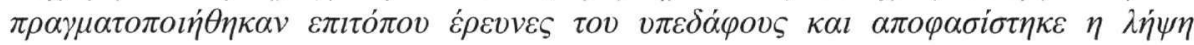

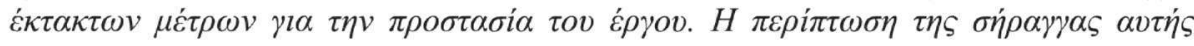

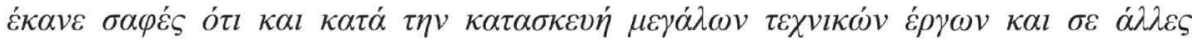




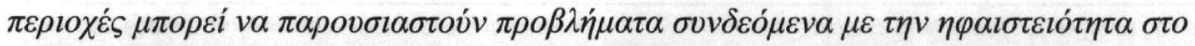

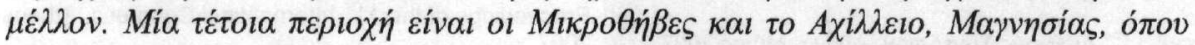

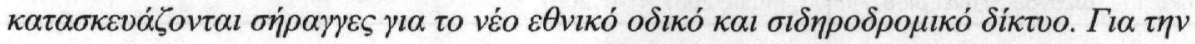

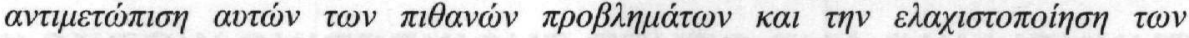

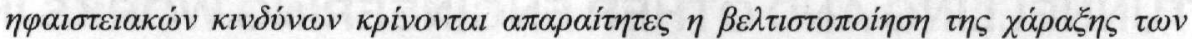

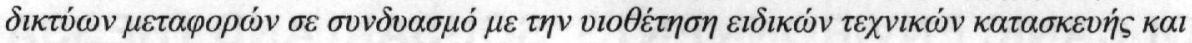
$\mu \varepsilon \dot{\tau} \rho \omega \nu \alpha \sigma \varphi \alpha \lambda \varepsilon i \alpha \varsigma$.

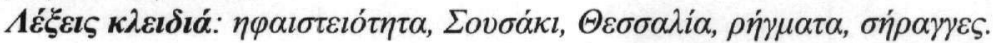

\section{Introduction}

Numerous engineering structures are under construction or planned as part of the main N-S and EW routes in Greece (PATHE Highways, Egnatia Odos and the new High Speed Railroad -HSRL; Fig. 1) running across regions known for their complex geology and intense morphology, their recent seismic activity (Papazachos and Papazachou 1997, Ambraseys and Jackson 1990) and numerous Quaternary faults (Bornovas and Rondogianni 1983, Caputo and Pavlides 1993), some of which are known to have cut roads and railroads (Papastamatiou and Mouyiaris 1986, Stiros 1995, Drakos et al. 2001), as well as areas of intense geotechnical instability; differential ground subsidence and fracturing (Stiros 2001, Kontogianni et al. in press) and landsliding (Fytrolakis and Antoniadis 1974, Marinos et al. 1997). Construction and operation of major geotechnical works at such areas often proved a difficult task because of sudden or gradually cumulating deformations and ground instability (Fytrolakis and Antoniadis 1974, Hoek and Marinos 2000). In such cases delays and increased cost for the completion of the projects proved unavoidable. A characteristic example is the Kallidromo railroad tunnel, in central Greece, where closures of up to $1 \mathrm{~m}$ were detected at sections crossing a fault zone. Excavation had to stop in 2003 and long parts of the tunnel were re-profiled (Kontogianni and Stiros 2005). Supplementary geological and geotechnical studies were carried out and the project is to continue with great delay under a new contract and a revised

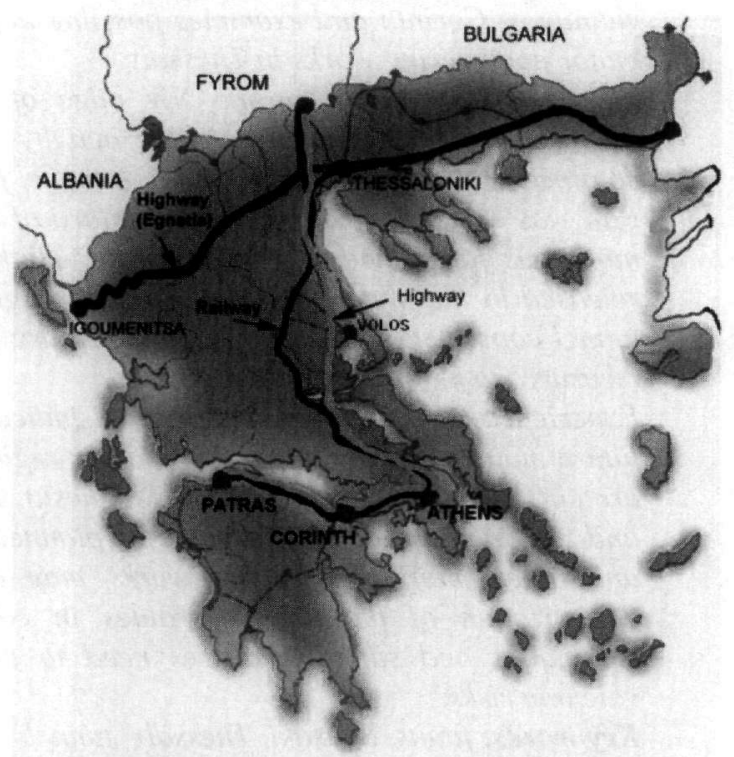

Figure 1 - Map of Greece with the main N-S and $E-W$ routes for the Highway and the Rail construction technique. Further North, in the Thessaly plain, transportation and utilities networks are affected by ground fissuring and subsidence produced by compaction of unconsolidated sediments due to groundwater over-pumping. Railway lines are regularly refitted to account for ground settlement, while a sudden ground fracture of the road caused a car accident (Pavlides unpubl. Data, Kontogianni et al. in press).

Besides seismic, tectonic and geotechnical problems, Quaternary volcanism in the Corinth area and southern Thessaly (Fyticas et al. 1985) represents another serious problem for major engineering works in central Greece. This is certainly a problem of local scale which has not been recognized in the past, but important for the construction and operation of major transportation works, especially of tunnels. 
Tunneling in volcanic environments is not unusual, and in fact the oldest tunnels excavated in such environments are those of Colli Albani volcano near Rome, Italy, in 394 BC (Funicello et al. 2003). Numerous tunnels have been excavated during the $20^{\text {th }}$ century through even young lavas of Etna, while more recently, a road tunnel was excavated in Arco Felice, Pozzuoli, Italy, though $5,000-500$ years old pyroclastics, in a area characterized by fumaroles and hot springs and recent ground uplift ('bradyseismic' events; Cortini and Barton 1993, Piochi pers. comm.). Other tunnels in young volcanic environments have been excavated through the Western Fjords of Iceland and New Zealand.

Although the risks of tunnelling through volcanoes is not unknown (Doyle 2001), tunnelling through the Sousaki dacitic field near Athens and Corinth faced some extraordinary problems. Examination of these problems and of the solutions adopted is a matter of major interest and may prove very helpful during the excavation of future tunnels through the volcanoes of S Thessaly.

\section{Tunneling through the Sousaki volcano (Corinth area)}

The Ag. Theodoroi tunnel, $1225 \mathrm{~m}$ long with a cross section of $110 \mathrm{~m}^{2}$, was excavated in 20012003 for the new Athens - Corinth High Speed Rail. This tunnel is adjacent to the Sousaki solfatara, probably formed in the last 2,000 years and a small surface normal fault associated with the 5 September 1953, magnitude 5.7 earthquake (Stiros 1995).

The geology of the area is known after Papastamatiou (1937) who first identified a reverse fault (Fig. 2) and argued that exposed dacites do not represent a laccolith, as was till then believed, but more recent, probably Pliocene volcanics; a conclusion subsequently confirmed by radiometric datings (3.9-2.7Ma, Fyticas et al. 1985). The geology of the area consists of Holocene to Pliocene sediments, mainly marls, conglomerates and alluvium, overlaying ophiolites thrusted over Mesozoic limestones, as well as Pliocene dacites, tectonised and weathered, locally taking the form of sand or clay, spread over an area of $16 \mathrm{~km}^{2}$ (Mettos et al. 1982, Mettos et al. 1988, Stiros 1991). In this environment a low-enthalpy geothermal field has been identified (Kavouridis and Fyticas, 1988).

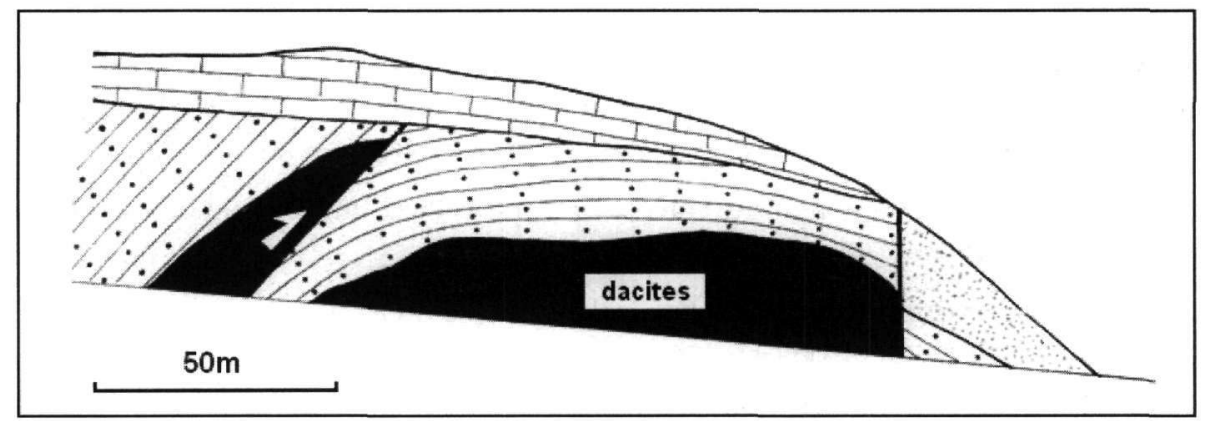

Figure 2 - Detail of the stratigraphy at the Sousaki volcano area, showing dacite intrusions along Neogene rocks. Modified after Papastamatiou (1937). Based on this observation the Pliocene volcanic activity in the area was first documented. The Ag. Theodori tunnel cuts through this volcanic dome

During excavation at the heading level, a fissure with an opening of several centimeters suddenly appeared at the tunnel floor. Soon after, temperature at the opening rose and a strong smell suffused the tunnel. Several workmen at the tunnel front had feeling of dizziness and breathing problems, which testifies to toxic gas penetration through the fault. Immediately geological, volcanic and geothermal supplementary investigations, mapping of the broader area and chemical analysis of released gases were carried out (Tsatsanifos and Polymenakos 2002). The main results of these analyses were: 
- the tunnel cuts through the dome of the Sousaki tunnel, not far from low-enthalpy geothermal fluids.

- geophysical studies at the area revealed that dacites, the main formation at the tunnel level, are characterized by numerous open fissures and cavities of relatively small dimensions (in most cases height 1 to $2 \mathrm{~m}$ and diameter 0.5 to $1 \mathrm{~m}$; Fig.3). These fissures are certainly not primary tectonic features, but shaking from any of the seismic sources in the wider region may lead to small dislocations and seriously affect the tunnel.

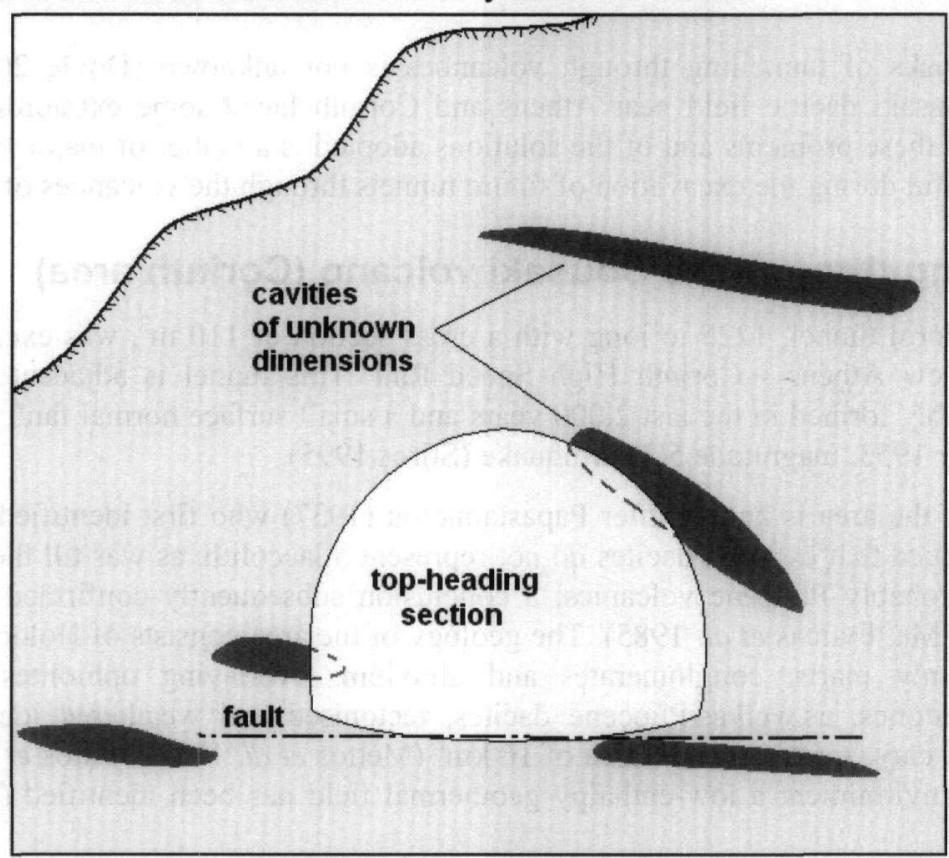

Figure 3 - A cross section of the Ag.Theodoroi tunnel at the area the fault appeared on the floor and $\mathrm{CO}_{2}$ was released in the opening. Geophysical studies revealed that cavities of unknown, probably small dimensions are scattered in the dacites close to the excavation and at the tunnel floor are linked by a system of several small-length faults

Based on the above results a revised construction procedure and continuous monitoring were decided. The measures adopted involved:

- Continuous measurements of the gas leakage at the areas near the geothermal gas storage area and construction of vent-escape pipes.

- Full closure of the tunnel section after the bench excavation at areas where cavities or instabilities were expected or met.

- Protection of the final lining against corrosion in case of gas leakage and construction of a fully-closed ring section lined by gas-proof membranes.

- Establishment of a continuous and systematic monitoring program recording the ground and tunnel wall movements during both the construction and the operation period, based on geotechnical and geodetic instrumentation.

Completion of the tunnel a few months later, proved the above revised construction procedure was successful and the Ag. Theodoroi tunnel represents an exemplary methodology for future tunnels at similar environments. 


\section{Volcanic activity and major engineering works in Thessaly}

A Late Pliocene-Quaternary volcanic centre, mainly consisting of a series of small lava outcrops, exists in the Volos - Kammena Vourla area and Psathoura Islet (Fig. 4). These volcanic centres mostly consist of basaltic andesites with high $\mathrm{K}_{2} \mathrm{O}$ or high $\mathrm{MgO}$ content and their source is deep, different from that of the calk-alkaline volcanics of the Southern Aegean Arc. Radiometric data indicate an age between 3.4 and 0.5 Ma (Marinos 1956/57, Innocenti et al. 1979, Fyticas et al. 1985). Except for lava flows, there is also evidence of modest eruptive activity with gas eruptions (mainly $\mathrm{SiO}_{2}$ and traces of $\mathrm{CO}_{2}$ and $\mathrm{SO}_{3}$ showing impuissant volcanic energy; Marinos 1963) in the last centuries. In addition, two small lakes (Zileria) in the Almyros area testify to relative recent phreatic eruptions (Marinos 1963, Marinos and Papakis 1965), memories of which are probably preserved in ancient myths (Stiros and Papageorgiou 1994). However, for lack of recent detailed studies, the details of the volcanism in the area and the associated risks remain unknown.

Volcanic activity in Thessaly has been associated with extensional tectonics at the NW edge of the North Aegean Trough (Fyticas et al. 1985). The Nea Aghialos and Microthives volcanoes, in particular, correlate with the fault which bounds the Pagasitic Gulf and the Almyros plain to the north and reactivated in 1980 (Papazachos et al. 1983, Ambraseys and Jackson 1990, Drakos et al. 2001). The Achilio, Lichades and Kammena Vourla volcanoes correlate with the fault controlling the Orei Straits which separate Euboea from the mainland, while Psathoura bounds the bathymetric escarpment of the North Aegean Trough to the south (Drakos et al. 2001). The wider area is tectonically very active, with several earthquakes of magnitude $6.0-7.0$ in the $20^{\text {th }}$ century (Papazachos and Papazachou 1997). In such an environment, seismic and tectonic activity may also trigger minor volcanic or post-volcanic activity.

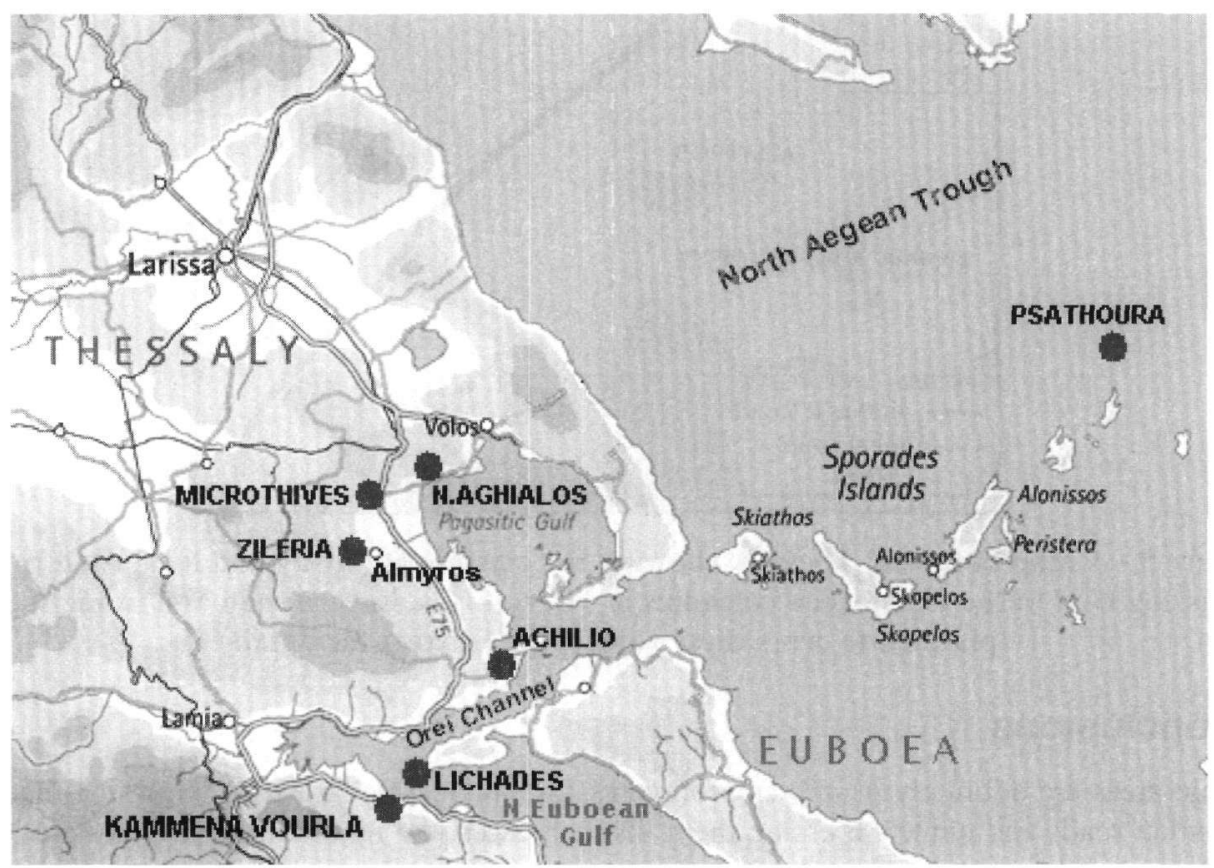

Figure 4 - The Quaternary volcanoes of the SE Thessaly volcanic complex (see text for references and details)

This region is crossed by the national highway and local road systems (Fig. 5) and other crucial infrastructure of national importance (utilities networks), while additional structures, tunnels etc. are planned as parts of a new Highway and Rail system. It is also important to notice that an 
immersed tunnel was planned between Kammena Vourla and Lichades Isles, i.e. along two volcanic centres, but this plan seems to have been abandoned.

Even in the case of a moderate volcanic activity, ground deformation, gas release and even eruptions, perhaps in combination with seismic and tectonic activity, are definitely threats to engineering works both during the stage of construction and during their operation. Experience from the Ag. Theodoroi tunnel suggests that such volcanic risks should be taken into consideration in the planning of the engineering works, even if differences in the characteristics of the volcanism in the two areas exist..

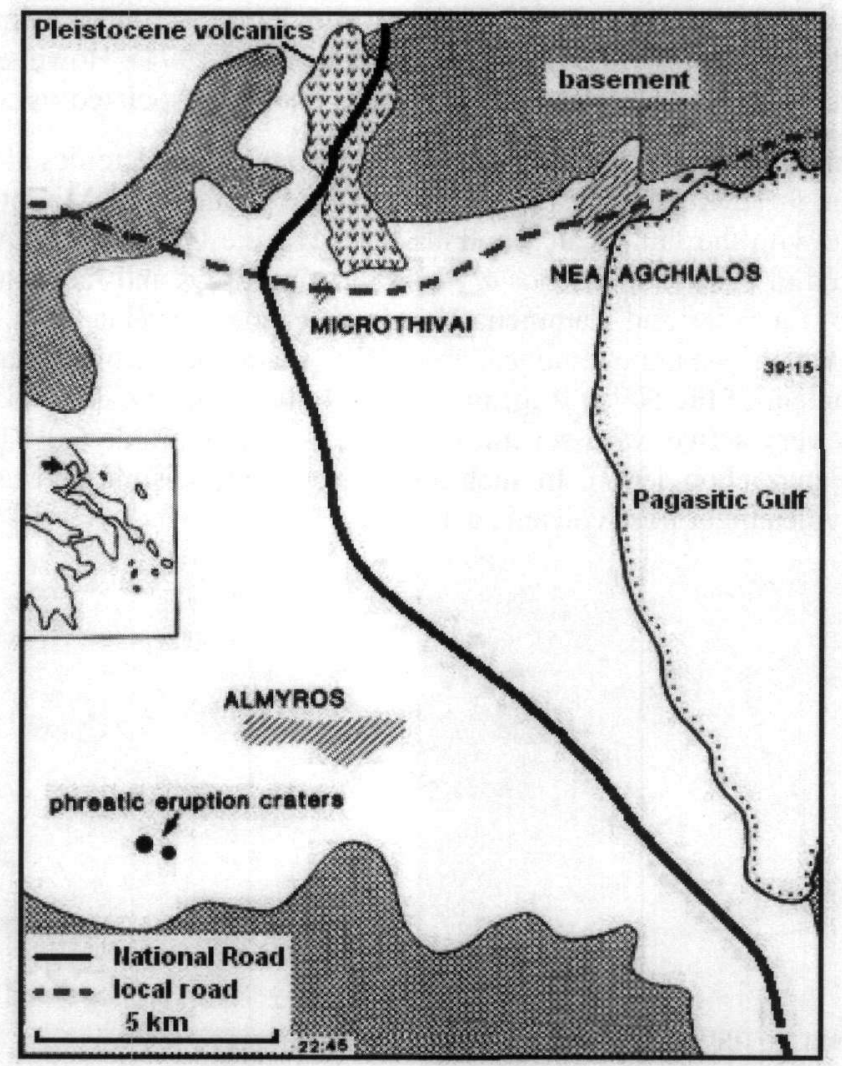

Figure 5 - A map of the SE Thessaly showing the existing Highway and local road routes passing next to the Pleistocene volcanics of Microthives. Future road and tunnels are planned to cross these volcanoes. See text for details

\section{Conclusions}

Volcanic areas are definitely hostile environments for engineering structures. Still, it is necessary to construct roads and tunnels crossing them. In such cases, the ignored hazards may prove high, even in apparently insignificant volcanoes such as that of Sousaki. For this reason, in view of the planned transportation networks and other major engineering works in Thessaly, the possible volcanic hazard should be seriously taken into consideration, both during the stage of their construction and of their operation. 


\section{Acknowledgements}

M. Piochi, G. Giordano, T. Gerlach and B. Scott are thanked for providing information on tunnels in young volcanic environments.

\section{References}

Ambraseys, N., and Jackson, J., 1990. Seismicity and associated strain of central Greece between 1890 and 1988, Geophys. J. Int., 101, 663-708.

Bornovas, J., and Rondogianni, T., 1983. Geological map of Greece, 1:500,000 scale, IGME, Athens.

Caputo, R., and Pavlides, S., 1993 Late Cainozoic geodynamic evolution of Thessaly and surroundings (central-northern Greece), Tectonophysics, 223, 339-362.

Cortini, M., and Barton, C., 1993. Nonlinear forecasting analysis of inflation-deflation patterns of an active caldera (Campi Flegrei, Italy), Geology, 21, 239-242.

Doyle, B.R., 2001. Hazardous Gases Underground: Applications to Tunnel Engineering, Marcel Dekker, Inc, New York, Basel, 375pp.

Drakos, A., Stiros, S., and Kiratzi, A., 2001. Fault-parameters of the 1980 (Mw 6.5) Volos (central Greece) earthquake from inversion of repeated leveling data, Bulletin of the Seismological Society of America, 91, 1673-1684.

Fytikas, M., Innocenti, F., Manetti, P., Mazzuoli, R., Peccerillo, A., and Villari, L., 1985. Tertiary to Quaternary evolution of volcanism in the Aegean region. In J. Dixon and A. Robertson (ed.), The Geological evolution of the Eastern Mediterranean, Sp. Publ. Geol. Soc. Lond., 17, 687-699.

Funiciello, R., Giordano, G., and De Rita, D., 2003. The Albano Maar Lake (Colli Albani Volcano, Italy): recent volcanic activity and evidence of pre-Roman age catastrophic lahar events, J. of Volcanology and Geothermal Res., 123, 43-61.

Fytrolakis, N., and Antoniadis, D., 1974. Landslides and geological conditions in the National Road Corinth-Patras, Psathopyrgos area, Mining and Metallurgical Chronicles, 20, 31-38. (in Greek)

Hoek, E., and Marinos, P., 2000. Predicting Squeeze, Tunnels and Tunnelling International, November, 45-51.

Innocenti, F., Manetti, P., Peccerilo, A., and Poli, G., 1979. Inner arc volcanism in the NW Aegean arc: geochemical and geochronological data, N. Jb. Miner. Mh., Jg., 145-158.

Kavouridis, T., and Fyticas, M., 1988. Goethermal study of the Sousaki area (Corinth region), unpublished IGME Report, 5526, Athens. (in Greek)

Kontogianni, V., and Stiros, S., 2005. Induced Deformation during Tunnel Excavation: Evidence from Geodetic Monitoring, Engineering Geology, 79(1-2), 115-126.

Kontogianni, V., Pytharouli, S., and Stiros, S. in press. Ground subsidence, Quaternary faults and vulnerability of utilities and transportation networks in Thessaly, Greece. Environmental Geology.

Marinos, G., 1956/57. The Achillion volcano in eastern Greece, Bull. of the Geological Society of Greece, 3, 64-72. (in Greek with English summary)

Marinos, G., 1963. Sur deux volcans embryonnaires de type maare, pres d'Almyros, Thessalie, Bull. Geol. Soc. Greece, 5, 108-114. (in Greek) 
Marinos, G, and Papakis, N., 1965. Sur deux petits lacs "Zileria" pres d' Almyros, Thessalie, Geol. Geophys. Res., IGME, 9, 175-194.

Marinos, P., Sotiropoulos, E., Yannatos, M., and Cavounidis, S., 1997. Increasing the stability of a failed slope by pumping, Malakasa landslide, Athens, Greece, Proc. Symposium Engineering Geology and the Environment., Athens, 1, 853-857

Mettos, A., Gaitanakis, P., Rondogianni, T., Bavay, P., Ioakim, C., Mitsaki, B., and Koutsouveli, A., 1982. Goelogical study of the region "Loutraki-Sousaki", Geothermal studies of PPC (Public Power Corp.), IGME.

Mettos, A., Rondogianni, T., and Bavay, P., 1988. Pleio-Pleistocene deposits at Sousaki Ag.Theodoroi (Corinth): Stratigraphy and Defoemations, Bull. of the Geological Society of Greece, 10(2), 91-111.

Papastamatiou, I., 1937. The Neogene volcanoes of Kromionia, PhD Thesis. University of Athens. (in Greek)

Papastamatiou, D., and Mouyiaris, N., 1986. The earthquake of April 30, 1954, in Sophades (central Greece), Geophys. J. R. astr. Soc., 87, 885-895.

Papazachos, B., and Papazachou, C., 1997. The earthquakes of Greece. Zitis, Thessaloniki, 304pp.

Papazachos, B., Panagiotopoulos D., Tsapanos, T., Mountrakis, D., and Dimopoulos, G., 1983. A study of the 1980 summer sequence in the Magnesia region of Central Greece, Geophys. $J$. R. astr. Soc., 75, 155-168.

Stiros, S., 1995. The 1953 seismic surface fault: Implications for the modeling of the Sousaki (Corinth area, Greece) Geothermal field, Journal of Geodynamics, 20, 167-180.

Stiros, S., and Papageorgiou, S., 1994. Post-Mesolithic evolution of the Thessalian landscape, In La Thessalie, Quinze annees de recherches archeologiques, 1975-1990, Bilans et perspectives, TAPA, Athens, 29-36.

Stiros, S., 2001. Rapid subsidence of the Thessaloniki (Northern Greece) coastal plain, 1960-1999, Engineering Geology, 61, 243-256.

Tsatsanifos, C., and Polymenakos, L., 2002. Excavation of the Ag.Theodoroi tunnel, The Bulletin of Tunnels, Greek Tunnelling Society. September issue, 2-5, Internet ref:: http://tunnelling.metal.ntua.gr/gts/Deltio/0209_Deltio.pdf. (in Greek) 